\title{
Comparison between Some Processed Dried Soup Products
}

\author{
Samiha M.El-Sayed ${ }^{1}$
}

\begin{abstract}
Soup has been widely consumed in the diet due to their flavour and palatable taste. Three blends of dried soup were processed from only chicken meat (blend A), mixture of chicken meat and mushroom (blend B) and mushroom only (blendC) and stored for 6 months at room temperature. The processed soups were compared with to commercial soup widely available in the local market. There were generally significant differences in proximate composition between processed blends and commercial soup. The results indicated that processed blends had the highest content of peroxide and TBA values. TPC, moulds and yeasts contents were increased by increasing the storage period. Blends (A) and (C) had higher essential amino acids comparing with blend (B). While, blend (c) had the highest oleic, linoleic and linolenic acids.
\end{abstract}

Keywords:soup-processed soup-stock soup-commercial dried soup -chicken soup-mushroom soup.

\section{INTRODUCTION}

Soup is a staple in the diet and it can increases appetite by stimulating the secretion of saliva and also assists peristalsis of the stomach to facilitate food intake. However, in modern life, less time is available for a cook to make a soup with delicious and palatable taste. An easy and convenient way of making a soup is to use a soup base in the form of a broth cube, granule or powder (Krejeave et al., 2007).Currently, commercial broth cubes available in the market include chicken, mushroom and seafood broth cubes (Chiang et al., 2007).They bear different traditional names, the most famous of which are beef, chicken stock(Krejeave et al., 2007).

Meat extract which is used to generate a meaty flavour can be substituted by beef bones or chicken legs extract with the addition of monosodium glutamate and sodium 5- ribonucleotide (Varnam\& Sutherland, 1995 and Kuroda \& Harada, 2004).

Stock is originally an extract from animal or plant tissue and is used as a flavouring base of cuisine.The same stock cane differ in taste and other features depending on the type and condition of the starting molecules and other ingredients and additives(Kohno $e t$ al.,2005).

Within this sector are included powdered soups, powdered instant soups, powdered cook-in-sauces, compressed stock cubes and instant gravy granules. The advantage of this type of product over their liquid equivalents is generally lower cost and easier transportation and storage (Ranken et al., 1997).

Instant soups or dried soups, precooked dehydrated soups are wide groups of dried food which play an important role in the nutrition since they fulfil most of the nutritional requirements of the consumer. Such soup is usually composed of either beef .chicken, sea food, or vegetable base depending on the type and name of the soup together with other complementary ingredients such as wheat flour, potato starch, vegetable fat, spices and table salt, in addition to some aromatic ingredients and/or additives (Krejcova et al, 2007).

According to Bulgarian Standard, (1975), dried soup (incorporating greater than one of the following ingredients): granulated meat, granulated vegetables, vegetables oil, tomato juice, paprika puree, sour or powder milk mushrooms and various condiments.

Because it is simple to prepare, relatively cheap, nutritious, and easy on the digestive system, chicken soup is a good food for winter convalescents. Probably more significant, sipping warm soup can clear the sinuses because of the steam ventilating into the nasal passages, serving as a natural decongestant, which also relieves cold and flu symptoms. Last but not least, chicken soup can be beneficial due to the placebo effect of comfort foods (Rennard et al., 2000).

The purpose of this work is to process some blends of precooked dried chicken and mushroom soups made of completely natural ingredients without any chemical additives and carry out a comparative study on comparison quality and shelf life with similar commercial products displayed at local market.

\section{MATERIALS AND METHODS}

\section{Materials:}

Three types of dried soup powder were laboratory prepared as follows:-

A- Normal chicken meat soup powder was prepared using only chicken meat powder in ratio of $0.5 \%$ of the total ingredients.

B- Dried mushroom soup powder containing 2.5, 5, 7.5 and $10 \%$ mushroom powder.

C- Dried blend soups containing chicken meat $(0.5 \%)$ and mushroom powder $(2.5,5,7.5$ and $10 \%)$.

\footnotetext{
${ }^{1}$ Food Science and Technology Dept., Faculty of Home Economics

Tanta, Al-Azhar Univ.,Egypt

Received May6, 2008, Accepted September17, 2008
} 
D- Six samples of local chicken meat soup powder were brought from some different local commercial places.

Table (1) shows the ingredients content of all dried soup powder prepared in laboratory.

All ingredients utilized in the preparation of dried soup together with samples of commercial dried soup were secured from the local market of Tanta. Soy protein concentrate was secured from the "Agriculture Research Center, Cairo, Egypt"while stearin was secured from "Oil Derivatives Company Alexandria, Egypt". All reagents utilized in the chemical analysis were analytically grade supplied by E, Merk Company, Darmstadt ,Germany.

Chicken meat powder was prepared from white leghorns spent laying hens weighing $1.5-2.0 \mathrm{~kg}$ and purchased from the local market in Tanta. The hens were slaughtered according to Islamic procedure and left 6-7 minutes to bleed completely. They scald by dipping in hot water $\left(60 \pm 5^{\circ} \mathrm{C}\right)$ for about one minute. Scalding loosens the feathers which were then easily manually removed. The carcasses were then eviscerated, thoroughly washed with running water then cooked, deboned, dried and finally milled according to the following flow sheet:-

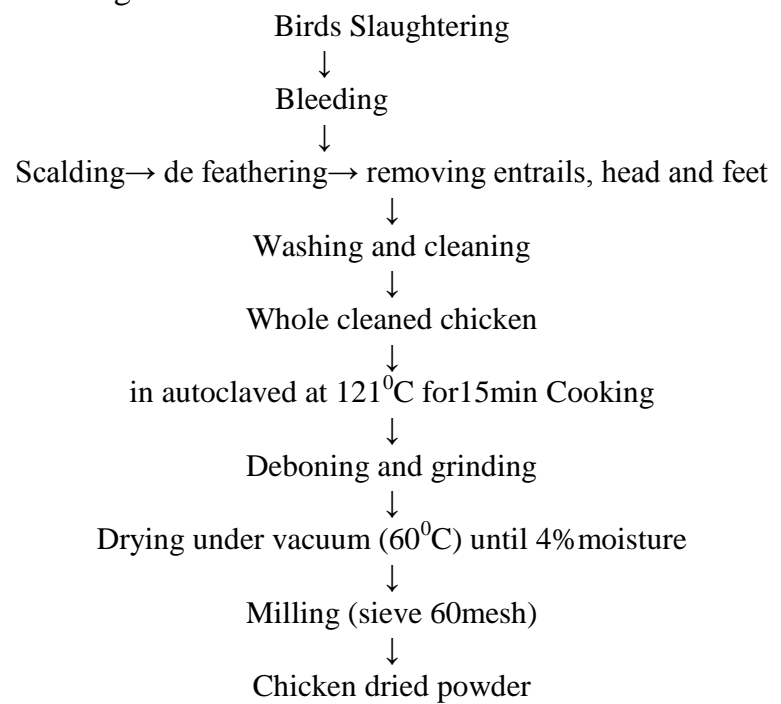

Fig1. Flow sheet for preparing dried chicken meat powder

\section{Preparation of dried mushroom powder}

Mushrooms powder (Agricus bisporus) was purchased from the local market, Alexandria, were prepared according the following flow sheet:-

Fresh mushroom

(Agricus bisporus)

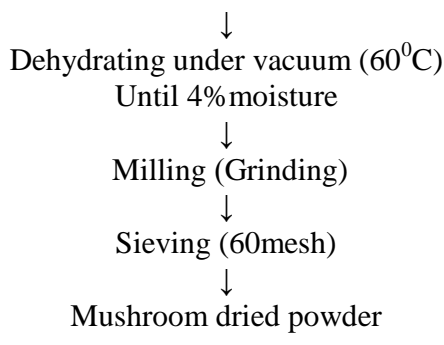

Fig2. Flow sheet for preparing dried mushroom powder

\section{Preparation of dried chicken meat and mushroom soup powder.}

The dried ingredients were weighted and was added to the melted stearin then homogenized for $30 \mathrm{~min}$ to form dough which was powdered in a templates of cubes $(3.5 \times 5 \mathrm{~cm})$, then covered with parchment paper.

\section{Analytical methods}

The proximate compositions (Moisture, protein, crude fat, crude fiber and ash content) of the investigated dried soups (processed blends and commercial) were carried out according to the AOAC (2000). The nitrogen factor used for crude protein calculation was 4.38 for mushroom soup base (Crisan \& Sands, 1978) and 6.25 for chicken soup bases (AOAC, 2000). The carbohydrate content (\%) was then obtained by difference. All determinations were carried out in triplicates.

Sodium chloride content of commercial and processed blends dried chicken soup was determined according (Anonymous, 1986).

The method described by AOAC (2000) was followed to estimate the minerals of both products and commercial soups .Gallen-Kamp Flam analyzer was used to estimate $\mathrm{Na}, \mathrm{K}$, while $\mathrm{Fe}$ and $\mathrm{Mg}$ were determined using Perkin Elmer Atomic Absorption Spectrophotometer. Total phosphorous was assayed calorimetrically at a wave length of $630 \mathrm{~nm}$ using a Spectronic-20 Spectrophotometer.

Peroxide value (PV) (as milliequivalant active oxygen $/ \mathrm{kg}$ fat) and thiobarbituric acid value (TBA) (as $\mathrm{mg}$ malonaldehyde/Kg fat) were determined as described by Egan (1987).

Preparation of fatty acid methyl esters from total lipids was performed according to the procedure of Radwan(1978)using a Perkin Elmer gas chromatography (gc-8410)with flame ionizing detector and glass column $2.5 \mathrm{~m} \times 3 \mathrm{~mm}$ i. $\mathrm{d}$, under the following conditions: column, packed with 3\% SP-2401 (Supelco chromatography suppliers, catalogue no. $1-1978$ ); column- temp.:170 ${ }^{\circ} \mathrm{C}$, detector temp.: $250^{\circ} \mathrm{C}$. 
Table 1. Ingredients of all dried soup powders prepared in laboratory

\begin{tabular}{|c|c|c|c|c|c|c|c|c|c|}
\hline \multirow[t]{3}{*}{ Ingredient } & \multicolumn{9}{|c|}{ Type of dried soup powder prepared(g/100g) } \\
\hline & \multirow[t]{2}{*}{$\mathrm{A}^{*}$} & \multicolumn{4}{|c|}{$\mathbf{B}^{* *}$} & \multicolumn{4}{|c|}{$\mathrm{C}^{* * * *}$} \\
\hline & & $\mathrm{B}(2.5)$ & $\mathbf{B}(\mathbf{5})$ & $\mathbf{B}(7.5)$ & B (10) & $\mathrm{C}(2.5)$ & $\mathrm{C}(5)$ & $\mathrm{C}(7.5)$ & $\mathbf{C}(\mathbf{1 0})$ \\
\hline Chicke nmeat powder & 0.5 & 'NU & NU & NU & NU & 0.5 & 0.5 & 0.5 & 0.5 \\
\hline Mushroom & - & 2.5 & 5 & 7.5 & 10 & 2.5 & 5 & 7.5 & 10 \\
\hline Wheat flour(75\%) & 17 & 15 & 12.5 & 10 & 7.5 & 14.5 & 12 & 9.5 & 7 \\
\hline Stearin & 20 & 20 & 20 & 20 & 20 & 20 & 20 & 20 & 20 \\
\hline Salt & 43 & 43 & 43 & 43 & 43 & 43 & 43 & 43 & 43 \\
\hline Herbs \& Spices & 9 & 9 & 9 & 9 & 9 & 9 & 9 & 9 & 9 \\
\hline Garlic oil & 1 & 1 & 1 & 1 & 1 & 1 & 1 & 1 & 1 \\
\hline Soy Pro.conc. (5\%) & 5 & 5 & 5 & 5 & 5 & 5 & 5 & 5 & 5 \\
\hline Gelatin & 2 & 2 & 2 & 2 & 2 & 2 & 2 & 2 & 2 \\
\hline Sugar & 1 & 1 & 1 & 1 & 1 & 1 & 1 & 1 & 1 \\
\hline Treacle & 0.2 & 0.2 & 0.2 & 0.2 & 0.2 & 0.2 & 0.2 & 0.2 & 0.2 \\
\hline Yeast extract & 0.3 & 0.3 & 0.3 & 0.3 & 0.3 & 0.3 & 0.3 & 0.3 & 0.3 \\
\hline Curcumas & 1 & 1 & 1 & 1 & 1 & 1 & 1 & 1 & 1 \\
\hline Total & 100 & 100 & 100 & 100 & 100 & 100 & 100 & 100 & 100 \\
\hline
\end{tabular}

$\mathrm{A}^{*}$ Dried chicken meat soup powder

$\mathrm{B}^{* * *}$ Dried mushroom soup powder

$\mathrm{C}^{* * * *}$ : Dried blend of chicken meat and mushroom soup powder 'NU: Not Used

Injection port temperature $290-300^{\circ} \mathrm{C}$, injection volume $1 \mu 1$. Nitrogen was used as carrier gas and a flow rate of $28 \mathrm{ml} / \mathrm{mint}$ Standard fatty acids methyl esters were used for identification. The area under each peak was measured by the triangulation method as percentage of each fatty acid with regard to the total area.

Amino acids composition was determined according to the method described by Duranti \&Cerletti (1979) using Beckman amino acid analyzer (Model 119CL).Amino acids composition was compared with RDA reported by FAO/WHO/UNU (1985).

Representative samples from soup blendes (at zero time and after storage fore six months) were taken for microbiological analysis.

Total plate count was counted using plate count agar (PCA) medium as described by Bridson (1990). The plates were incubated at $37 \pm 2^{\circ} \mathrm{C}$ for $24 \mathrm{hrs}$. Most probable number (MPN) of coliform bacteria was estimated using Macconkey broth as described by Bridson (1990). The tubes were incubated at $37 \pm 2^{\circ} \mathrm{C}$ for 48 hrs. Moulds and yeast counts were determined by plating on acidified potato dextrose agar medium (Difco). Plates were incubated at $25 \pm 2^{\circ} \mathrm{C}$ for 5 days (Nottingham, 1971).

Organoleptic evaluation of the commercial and processed blends dried soups were performed by 15 panelists of Food Sci. and Technology Dept.Fac. of Home Economics, AL-Azher Univ. Tanta according to the method of Fey\& Regenstein (1982)and Meilgaard et al.,(1999). For achieving such a purpose soup of 0.6$0.7 \%$ concentrate $(\mathrm{W} / \mathrm{V})$ was cooked in water for $5 \mathrm{~min}$.
Palatability tests were in terms of taste, odour, colour, texture and overall acceptability for soups were carried out .The soups were judged in water, stuffed grape leaves and Jewy's mallow (molokhia).

Organoleptic values and all determinations were analyzed statistically using SPSS (1999) version 9 to calculate the mathematical significantly difference at $\mathrm{P}>0.05$.

\section{RESULTS AND DISCUSSIONS}

\section{Chemical composition of processed and commercial dried soups:}

Chemical composition of dried soups were determined for both processed (A, B and C blend) and commercial soup samples. Table 2 show that the moisture content of blends $\mathrm{A}, \mathrm{B}(2.5), \mathrm{B}(5), \mathrm{C}(2.5)$ and $\mathrm{C}(7.5)$ were contained 13.6, 11.6 and 11.7, 15.20, $15.9 \%$ moisture, respectively. The highest values were exerted by the correspond (C) blend dried soup. The table also shows that blend $\mathrm{C}$ had the highest figures of moisture. It also shows that the moisture content of commercial dried soup ranged from 5.21 \pm 0.08 to $6.10 \pm 0.008 \%$.

In addition, among the nine blends of laboratory prepared dried soups, blend A had the lowest protein content, the lowest ash and the lowest crude fiber content. Blends B had the highest protein, ash and fiber content, whereas blend B had in-between contents of protein, ash and fiber.

The increase of protein and fiber in the laboratory prepared dried soup as compared to the commercial types could be attributed to the mushroom content, 
Table 2. Chemical composition of some blends and commercial dried soups(\%)

\begin{tabular}{|c|c|c|c|c|c|c|}
\hline Blends \& commercal & Moisture & Protein & Crude fat & Ash & ***** Carbohydrate & Crude fiber \\
\hline $\mathbf{A}^{* * *}$ & $13.6 \pm 0.15^{\mathrm{bC}}$ & $5.31 \pm 0.6^{\mathrm{e}}$ & $20 \pm 0.5^{\mathrm{a}}$ & $4.60 \pm 0.2^{\mathrm{c}}$ & $54.84^{\mathrm{bc}}$ & $1.65 \pm 1.5^{\mathrm{a}}$ \\
\hline $\left.\mathrm{B} \frac{}{(2.5} \%\right)$ & $15.26 \pm 0.32^{\mathrm{ab}}$ & $10.69 \pm 0.2^{c}$ & $19.9 \pm 0.2^{b}$ & $5.6 \pm 0.0^{\mathrm{ab}}$ & $44.81^{\mathrm{d}}$ & $3.74 \pm 0.9^{\mathrm{a}}$ \\
\hline B $(5.0 \%)$ & $13.26 \pm 0.32^{b}$ & $11.69 \pm 0.0^{\mathrm{b}}$ & $20.1 \pm 0.7^{\mathrm{a}}$ & $5.86 \pm 0.7^{\mathrm{a}}$ & $45.35^{\mathrm{d}}$ & $3.74 \pm 1.3^{\mathrm{a}}$ \\
\hline B $(7.5 \%)$ & $15.9 \pm 0.00^{\mathrm{a}}$ & $12.46 \pm 0.4^{\mathrm{b}}$ & $19.7 \pm 0.3^{\mathrm{b}}$ & $6.03 \pm 0.9^{\mathrm{a}}$ & $56.41^{\mathrm{a}}$ & $3.81 \pm 0.8^{\mathrm{a}}$ \\
\hline B $(10 \%)$ & $9.9 \pm 0.11^{\mathrm{de}}$ & $13.21 \pm 0.2^{\mathrm{a}}$ & $19.4 \pm 0.5^{b}$ & $6.87 \pm 0.1^{\mathrm{a}}$ & $46.78^{\mathrm{e}}$ & $3.84 \pm 0.5^{\mathrm{a}}$ \\
\hline$\overline{\mathrm{C}}(2.5 \%)$ & $11.6 \pm 0.25^{\mathrm{cd}}$ & $6.81 \pm 0.0^{\mathrm{d}}$ & $20 \pm 0.8^{\mathrm{a}}$ & $4.80 \pm 0.8^{b}$ & $55.02^{\mathrm{ab}}$ & $1.77 \pm 0.8^{\mathrm{d}}$ \\
\hline $\mathrm{C}(5.0 \%)$ & $11.7 \pm 0.55^{\mathrm{c}}$ & $7.66 \pm 0.5^{\mathrm{d}}$ & $19.8 \pm 0.1^{\mathrm{b}}$ & $4.82 \pm 0.7^{\mathrm{b}}$ & $53.92^{\mathrm{d}}$ & $2.1 \pm 0.8^{\mathrm{c}}$ \\
\hline $\mathrm{C}(7.5 \%)$ & $9.6 \pm 0.33^{\mathrm{d}}$ & $8.36 \pm 0.2^{\mathrm{d}}$ & $19.8 \pm 0.9^{b}$ & $4.90 \pm 0.3^{\mathrm{b}}$ & $55.52^{\mathrm{a}}$ & $2.2 \pm 0.6^{\mathrm{c}}$ \\
\hline $\mathrm{C}(10 \%)$ & $8.6 \pm 0.15^{\mathrm{e}}$ & $8.98 \pm 0.1^{\mathrm{cd}}$ & $19.8 \pm 1.1^{\mathrm{b}}$ & $5.1 \pm 0.4^{\mathrm{b}}$ & $54.65^{\mathrm{cd}}$ & $2.87 \pm 0.2^{\mathrm{b}}$ \\
\hline \multicolumn{7}{|l|}{ Commercial } \\
\hline$\overline{1}$ & $5.85 \pm 0.05^{\mathrm{b}}$ & $2.12 \pm 0.09^{\mathrm{de}}$ & $8.03 \pm 0.2^{b}$ & $5.36 \pm 0.0^{\mathrm{b}}$ & $77.99 \pm .16 \mathrm{c}$ & $0.63 \pm 0.10^{\mathrm{d}}$ \\
\hline 2 & $5.21 \pm 0.08^{\mathrm{a}}$ & $2.21 \pm 0.10^{\mathrm{e}}$ & $6.05 \pm .102^{\mathrm{a}}$ & $5.15 \pm .04^{\mathrm{a}}$ & $80.81 \pm .205 f$ & $0.55 \pm 0.04^{\mathrm{cd}}$ \\
\hline 3 & $5.81 \pm 0.34^{\mathrm{b}}$ & $1.85 \pm 0.104^{\mathrm{c}}$ & $14.65 \pm .16^{\mathrm{e}}$ & $5.81 \pm .11^{\mathrm{c}}$ & $71.53 \pm 0.31 b$ & $0.47 \pm 0.00^{\mathrm{bc}}$ \\
\hline 4 & $6.02 \pm 0.110^{\mathrm{b}}$ & $1.14 \pm 0.00^{\mathrm{a}}$ & $10.26 \pm .46^{c}$ & $5.43 \pm 0.0^{\mathrm{b}}$ & $76.53 \pm 0.355 d$ & $0.43 \pm 0.00^{\mathrm{b}}$ \\
\hline 5 & $6.10 \pm 0.008^{\mathrm{b}}$ & $1.99 \pm 0.01^{\mathrm{d}}$ & $18.07 \pm .01^{\mathrm{f}}$ & $5.93 \pm 0.0^{\mathrm{c}}$ & $67.56 \pm 0.57 a$ & $0.33 \pm 0.00^{\mathrm{a}}$ \\
\hline 6 & $5.98 \pm 0.24^{\mathrm{b}}$ & $1.34 \pm 0.00^{\mathrm{b}}$ & $13.82 \pm .0^{\mathrm{d}}$ & $5.35 \pm 0.0^{\mathrm{b}}$ & $73.20 \pm 0.27 \mathrm{c}$ & $0.30 \pm 0.00^{\mathrm{a}}$ \\
\hline
\end{tabular}

$\mathrm{A}^{*}$ : Dried chicken meat soup powder

$\mathrm{B}^{* *}$ : Dried mushroom soup powder

$\mathrm{C}^{* * * *}:$ Dried blend of chicken meat and mushroom soup powder

**:** Carbohydrate by difference.

Mean \pm standard error $(n=3)$

Means within raw with different letters are significantly $(\mathrm{p}<0.05)$

especially that both protein and fiber contents increased among the different types of laboratory prepared dried soup by increasing the percentage of mash room. Similarly, the higher content of carbohydrate in laboratory prepared dried soup as compared to the commercial types could be attributed to the added wheat flower as ingredients. The standard reported that moisture content should be less than $10 \%$ ( Bulgarian Standard, 1975).Flynn\&Fox(1981)found that moisture content range from $(1.4-6.6)$ with a mean of $4.48 \mathrm{~g} / 100 \mathrm{~g}$ in 17 types of dried soup. The final moisture content of dried soup depends on the product and must be low enough to prevent growing microorganisms such as molds (Axtell, 1992).

Soluble sugars usually contribute a sweet taste in broth cubes (Litchfield, 1967). Chiang et al., (2007) reported that the carbohydrate and protein contents of four broth cubes were 17.21-21.6\% and 11.4-14.7\% respectively. Also, lactose and sucrose were found higher in chicken broth cubes than in mushroom and seafood broth cubes.

As shown in Table (2), processed blends and commercial dried soup samples contained considerable amounts of crude fat. Processed blends dried soup contained higher fat content (which ranged from 19.4 to $20.8 \%$ ) compared to commercial soup samples (which ranged from 8.03 to $18.07 \%$ ). The same results shows that C (2.5) blend dried soup, which contain chicken meat powder and mushroom powder had higher fat content than another blends. Generally, Processed

blends dried soup had the highest fat content as compared to commercial soup. According to Chiang et al., (2007) a fat content was the highest $21.30-24.63 \%$ in dried soup.

The same results showed that ash content was ranged from 5.15 to $5.93 \%$ whereas 4.60 to $6.87 \%$, respectively in commercial and processed dried soup. The ash contents of four broth cubes were the highest among the proximate components and in the range of 38.62$44.75 \%$, whereas fat contents were the second highest 21.30-24.63\% (Chiang et al., 2007).

From the aforementioned data it could be noticed that the crude fiber was higher in processed blends dried soup samples than commercial samples, on the other hand the commercial dried soup samples showed higher value of carbohydrates. The highest content of crude fiber was noticed in (B) blend dried soup; the increased in crude fiber resulted in increased percentage of plant sources.

\section{Minerals content of some processed blends and commercial dried soup:-}

Data presented in Table(3) show that the mean of the macro-elements content of some processed blends and commercial dried soups can be ranked in the following descending order: $\mathrm{Na}, \mathrm{K}, \mathrm{P}$ and $\mathrm{Mg}$, whereas the microelement can be descending as Fe.

It can be seen from the above mentioned data (Table 4) that (A) processed blend soup had the highest content of $\mathrm{Na}(1882 \mathrm{mg} / 100 \mathrm{~g})$ followed by (C) processed blend 
soup which ranged from 1855 to $1878 \mathrm{mg} / 100 \mathrm{~g}$ at different mixing ratio. Data indicated that $(\mathrm{C})$ processed blend soup had the highest content of $\mathrm{Fe}, \mathrm{K}$, and $\mathrm{Mg}$ (at level 5, 7.5 and 10\%), which ranged from 12.30-12.95; 566-611 and 116-148 mg/ 100g, respectively.

The results clearly indicated that the mineral content such as $\mathrm{Na}, \mathrm{Fe}, \mathrm{K}, \mathrm{P}$ and $\mathrm{Mg}$ were ranged from 18301963 ; 6.31-12.14; 267-344; $109-160$ and $40-77 \mathrm{mg} /$ $100 \mathrm{~g}$, respectively for commercial dried soup samples.

Commercial dried soup samples were higher in $\mathrm{Na}$ content than those processed blends dried soup and lower than other minerals, this may be due to high percentage of sodium chloride which was added to commercial as improvement the taste or as preservation material for the final product. Mushroom is a source of some nutrients such as phosphorous, iron, thiamine, riboflavin and niacin (Kalac\& Svoboda, 2000).

Generally, the results indicate the products are considered as good sources of $\mathrm{Na}, \mathrm{K}, \mathrm{P}, \mathrm{Mg}$ and $\mathrm{Fe}$

Amino acids content of some processed blends dried soup

Amino acids pattern (calculated as g/ 100g protein) of some processed blends dried chicken soup samples are presented in Table(4). The illustrated results indicated that the variations in amino acids patterns could be attributed to the type of blend, mixing ratio and source of protein present in blends (animals or plants protein).
It is obvious from the results in Table (4) that most of non essential amino acid in (B) blend dried chicken soup samples (at all mixing ratio) were higher than those found in (A) and (C) blends dried soup. This could be attributed to the presence of mushroom as a major source of proteins in this bends (which known as a vegetable protein). It is well known that vegetable proteins are deficient in some amino acids such as essential amino acids comparing with amino acids in animal proteins. Kumiori et al, (1976) reported that the quality of mushroom protein is valued, better than that of cereal grains and legumes due to the presence of all essential amino acids.

Meanwhile essential amino acids content (such as lysine, leucine, phenylalanine, methionine and tryptophan) of (A) and (C) blends dried soup was higher than other amino acids which is daily attributed to the presence of meat (as all ratio) in these blends, these due to presence chicken meat (as animal protein) in this blends. It is clear from the same data that Glutamic, theronine and lysine, histidine were higher amino acids in (B) blend specially when added mushroom at level of 7.5 and $10 \%$. The results clearly indicate that the most essential amino acid contents of all kinds of the blend soups were lower as compared to pattern FAO/WHO/UNU (1985). Data indicated than threonine was considered to be the first limiting amino acid in (B) and (C) blends except for (A) blend, while lysine was the second limiting amino acid for $(\mathrm{C})$ blend at $5,7.5$ and $10 \%$ concentrations.

Table 4. Amino acids(A.A.) composition(g/100g protein) of some processed blends dried soups

\begin{tabular}{|c|c|c|c|c|c|c|c|c|c|c|}
\hline \multirow{2}{*}{$\begin{array}{l}\text { Blends } \\
\text { Amino acids }\end{array}$} & \multirow[t]{2}{*}{$\mathrm{A}^{*}$} & \multicolumn{4}{|c|}{$\mathbf{B}^{* * *}$} & \multicolumn{4}{|c|}{$\mathbf{C}^{* * * * *}$} & \multirow[b]{2}{*}{ RDA } \\
\hline & & $\mathrm{B}(2.5 \%)$ & B(5\%) & $\mathrm{B}(7.5 \%)$ & B(10\%) & $\mathrm{C}(2.5 \%)$ & $\mathrm{C}(5 \%)$ & $\mathrm{C}(7.5 \%)$ & $\mathrm{C}(\mathbf{1 0 \%})$ & \\
\hline "Essential A.A. & & & & & & & & & & \\
\hline Lysine & 4.01 & 3.00 & 3.14 & 3.21 & 3.26 & 5.30 & 6.81 & 6.85 & 6.15 & 5.50 \\
\hline Leucine & 4.44 & 1.17 & 1.21 & 1.22 & 1.26 & 4.52 & 4.59 & 4.61 & 4.62 & 7.00 \\
\hline Iso-Leucine & 4.52 & 0.70 & 0.74 & 0.81 & 0.85 & 4.63 & 4.77 & 4.85 & 5.05 & 4.00 \\
\hline Phenylalanine & 2.14 & 1.05 & 1.12 & 1.15 & 1.17 & 2.22 & 2.35 & 2.51 & 2.71 & 5.6 \\
\hline Methionine & 2.17 & 1.26 & 1.32 & 1.33 & 1.37 & 2.25 & 2.42 & 2.50 & 2.54 & 3.5 \\
\hline Tryptophan & 0.90 & 0.48 & 0.44 & 0.42 & 0.34 & 0.99 & 1.12 & 1.13 & 1.20 & - \\
\hline Threonine & 2.99 & 4.35 & 4.42 & 4.42 & 4.45 & 4.03 & 4.10 & 4.13 & 4.19 & 4.00 \\
\hline Valine & 5.65 & 4.23 & 4.13 & 4.03 & 3.85 & 5.10 & 5.02 & 4.87 & 4.62 & 5.00 \\
\hline \multicolumn{11}{|l|}{ Semi -essential } \\
\hline Arginine & 4.60 & 3.60 & 3.87 & 3.88 & 3.95 & 4.81 & 4.95 & 5.15 & 5.19 & - \\
\hline Histedine & 1.05 & 2.44 & 2.50 & 2.65 & 2.72 & 1.11 & 1.25 & 1.30 & 1.45 & - \\
\hline Serine & 1.21 & 1.05 & 1.10 & 1.12 & 1.14 & 1.20 & 1.27 & 1.28 & 1.34 & - \\
\hline Cystine & 1.20 & 0.87 & 0.80 & 0.69 & 0.60 & 1.21 & 1.25 & 1.25 & 1.28 & 3.5 \\
\hline \multicolumn{11}{|l|}{ Non-essential } \\
\hline Glutamic & 8.55 & 16.66 & 17.05 & 19.22 & 20.05 & 10.25 & 10.63 & 10.87 & 11.03 & - \\
\hline Proline & 5.73 & 4.92 & 4.82 & 4.77 & 4.72 & 5.52 & 5.77 & 5.90 & 4.96 & - \\
\hline
\end{tabular}

"According to Sanders and Emery (2003)

RDA for adults suggested by FAO/WHO/UNU for adults (1985)

$\mathrm{A}^{*}$ : Dried chicken meat soup powder

$\mathrm{B}^{* *}$ : Dried blend of chicken meat and mushroom soup powder

$\mathrm{C}^{* * * *}$ : Dried mushroom soup powder 
Fatty acids composition $(\%)$ of some processed blends dried soups:-

Results illustrated in Table (5) show the ratio of fatty acids composition of some processed blends dried soup. From the obtained results, it could be concluded that lipid of (B) processed blend soup samples contained the lowest percentage of total saturated fatty acids as compared to (A) and (C) processed blends. Of the unsaturated fatty acids had higher percentage of total acids $(31.75,32.54,32.60$ and $33.56 \%)$ in $\mathrm{C}(2.5)$, (5), (7.5) and (10\%), respectively when compared to other blends. Meanwhile, oleic $\left(\mathrm{C}_{18: 1}\right)$, linoleic $\left(\mathrm{C}_{18: 2)}\right)$ and linolenic $\left(\mathrm{C}_{18: 3)}\right.$ acids gave the highest values in (B) processed blend dried soup samples.

The results indicate that palmitic acid $\left(\mathrm{C}_{16: 0}\right)$ had the highest value comparing with other fatty acids in all blends and at all levels. Generally, the total saturated fatty acids were higher than the total unsaturated ones in all processed blends dried soup.

\section{Storage stability of dry soup blendes}

\section{Peroxide value}

The peroxide value is one of the chemical methods of some processed blends dried soup during 6 months. The obtained result indicates that peroxide value increased markedly and progressively up to 6 months of storage for all processed blends dried soup. The increment of peroxide value for (A) and (B) blends was insignificant, according to Goldman \& Chodlia(1966) ,the increase of peroxide value could be attributed to the formation of peroxides, aldehydes, ketons and free fatty acids.

From these results, it could be noticed that the fat oxidation took place during storage as indicated by the higher peroxide values as a result of oxidation of unsaturated fatty acids, particularly the polyunsaturated fatty acids and the formation of hydro peroxides which generally are called peroxides or primary products of oxidation (Gray,1975). Also, the peroxide value was fluctuating during storage. Since, it changed between increasing and decreasing which may be attributed to the possibility that some peroxides might have been formed and other could have been decomposed and the ratio between both those formed and those destroyed affects the final peroxide value. In addition, other types of reactions may be occurred since the peroxides are unstable products which may be destroyed to carbonyl compounds and tend to react with free amino groups, vitamins, etc. and as a result of these kinds of reactions loss of essential nutrients have been observed during processing (Karel,1973; Pearson et.al.,1977 and Gray,1978 ).

\section{Thiobarbituric acid (TBA) value}

It is well known that the thiobarbituric acid test (determination of malonaldehyde formed by the breakdown of peroxides derived from hydro peroxides) is one the widely used tests for measuring the deterioration of lipids. This test is a sensitive test for the decomposition products of highly unsaturated fatty acids which do not appear in peroxide determination (Younathan et al., 1980 and Melton, 1983).

TBA value (as malonaldehyde $\mathrm{mg} / \mathrm{Kg}$ dry matter) of studied soup samples (processed blends) was determined for process-blends soup which stored for 6 months at room temperature. Data presented in Table (7) indicate that the TBA value slightly increased as a result of storage in all processed blends dried soup samples. The same results indicate that no significant differences in TBA values are present among the blends of dried soup during storage.

Table 5. Fatty acids composition of some processed blends dried soup

\begin{tabular}{|c|c|c|c|c|c|c|c|c|c|}
\hline \multirow{2}{*}{$\begin{array}{l}\text { Blends } \\
\text { Fatty acids }\end{array}$} & \multirow[t]{2}{*}{$\bar{A}$} & \multicolumn{4}{|c|}{$\mathbf{B}$} & \multicolumn{4}{|c|}{$\mathrm{C}^{\prime \prime}$} \\
\hline & & $\begin{array}{c}\mathbf{B} \\
(\mathbf{B} .5 \%)\end{array}$ & $\begin{array}{c}B \\
(5 \%)\end{array}$ & $\underset{(7.5 \%)}{\mathbf{B}}$ & $\begin{array}{c}\mathbf{B} \\
(\mathbf{1 0 \%})\end{array}$ & $\begin{array}{c}\mathrm{C} \\
(2.5 \%)\end{array}$ & $\begin{array}{c}C \\
(5 \%)\end{array}$ & $\begin{array}{c}\mathrm{C} \\
(7.5 \%)\end{array}$ & $\begin{array}{c}\mathrm{C} \\
(\mathbf{1 0 \%})\end{array}$ \\
\hline C14:0 & 12.58 & 11.24 & 11.10 & 11.05 & 10.94 & 12.80 & 13.12 & 13.81 & 13.81 \\
\hline C16:0 & 41.64 & 37.95 & 38.04 & 38.17 & 38.64 & 38.50 & 36.41 & 36.25 & 36.25 \\
\hline C18:0 & 20.40 & 18.59 & 18.35 & 18.20 & 17.86 & 19.08 & 18.95 & 18.67 & 18.67 \\
\hline C16:1 & 1.0 & 0.81 & 0.76 & 0.75 & 0.70 & 0.94 & 0.92 & 0.89 & 0.89 \\
\hline C18:1 & 23.57 & 27.01 & 27.95 & 28.06 & 28.82 & 25.40 & 25.63 & 26.10 & 26.10 \\
\hline C18:2 & 0.81 & 3.77 & 3.76 & 3.62 & 3.86 & 1.98 & 2.09 & 2.19 & 2.19 \\
\hline C18:3 & * ND & 0.15 & 0.15 & 0.16 & 0.16 & 0.08 & 0.13 & 0.14 & 0.14 \\
\hline C20:4 & ND & 0.01 & 0.01 & 0.01 & 0.02 & ND & ND & ND & ND \\
\hline Others(unknown) & ND & 0.47 & ND & ND & ND & 0.67 & 2.75 & 1.94 & 1.94 \\
\hline Total saturated \% & 74.62 & 67.78 & 67.49 & 67.42 & 66.44 & 70.93 & 68.48 & 68.73 & 68.73 \\
\hline Total unsaturated \% & 25.38 & 31.75 & 32.54 & 32.60 & 33.56 & 27.46 & 28.77 & 29.32 & 29.32 \\
\hline U/S ratio" & $0.34: 1$ & $0.47: 1$ & $0.48: 1$ & $0.48: 1$ & $0.51: 1$ & $0.39: 1$ & $0.42: 1$ & $0.43: 1$ & $0.43: 1$ \\
\hline
\end{tabular}

$\mathrm{A}^{*}$ : Dried chicken meat soup powder

$\mathrm{B}^{* *}$ : Dried mushroom soup powder

$\mathrm{C}^{* * * *}$ : Dried blend of chicken meat and mushroom soup powder

$\mathrm{ND}^{* *}$ : not detected "as\% of total fatty acids 
Table 6. Peroxide value of some blends dried soup during storage

\begin{tabular}{|c|c|c|c|c|c|c|c|c|c|}
\hline \multirow{2}{*}{ Blendes } & \multirow[b]{2}{*}{$A^{*}$} & \multicolumn{4}{|c|}{$\mathbf{B}^{* *}$} & \multicolumn{4}{|c|}{$\mathbf{C}^{* * *}$} \\
\hline & & $\begin{array}{c}\text { B } \\
(2.5 \%)\end{array}$ & $\begin{array}{c}\text { B } \\
(5 \%)\end{array}$ & $\begin{array}{c}\text { B } \\
(7.5 \%)\end{array}$ & $\begin{array}{c}\text { B } \\
(10 \%)\end{array}$ & $\begin{array}{c}\mathrm{C} \\
(2.5 \%)\end{array}$ & $\begin{array}{c}\mathrm{C} \\
(5 \%)\end{array}$ & $\begin{array}{c}\mathrm{C} \\
(7.5 \%)\end{array}$ & $\begin{array}{c}\mathrm{C} \\
(10 \%)\end{array}$ \\
\hline 0 & $1.08 \pm 2.2^{\mathrm{a}}$ & $1.08 \pm 0.9^{\mathrm{a}}$ & $1.08 \pm 0.6^{\mathrm{a}}$ & $1.08 \pm 0.3^{\mathrm{a}}$ & $1.08 \pm 1.2^{\mathrm{a}}$ & $1.08 \pm 1.2^{\mathrm{a}}$ & $1.08 \pm 0.2^{\mathrm{a}}$ & $1.08 \pm 0.7^{\mathrm{a}}$ & $1.08 \pm 0.8^{\mathrm{a}}$ \\
\hline 1 & $1.28 \pm 0.3^{\mathrm{a}}$ & $1.21 \pm 0.7^{\mathrm{b}}$ & $1.29 \pm 0.2^{\mathrm{a}}$ & $1.30 \pm 0.6^{\mathrm{a}}$ & $1.28 \pm 0.8^{\mathrm{a}}$ & $1.26 \pm 0.7^{\mathrm{a}}$ & $1.26 \pm 0.6^{\mathrm{a}}$ & $1.24 \pm 0.6^{\mathrm{b}}$ & $1.23 \pm 2.0^{\mathrm{b}}$ \\
\hline 2 & $1.39 \pm 4.3^{\mathrm{a}}$ & $1.34 \pm 0.8^{b}$ & $1.36 \pm 0.1^{\mathrm{a}}$ & $1.44 \pm 0.7^{\mathrm{a}}$ & $1.36 \pm 0.9^{\mathrm{a}}$ & $1.33 \pm 0.6^{\mathrm{b}}$ & $1.32 \pm 0.6^{\mathrm{b}}$ & $1.34 \pm 1.2^{\mathrm{b}}$ & $1.33 \pm 0.5^{\mathrm{b}}$ \\
\hline 3 & $1.53 \pm 0.1^{\mathrm{a}}$ & $1.50 \pm 0.5^{\mathrm{a}}$ & $1.49 \pm 0.6^{\mathrm{a}}$ & $1.50 \pm 0.6^{\mathrm{a}}$ & $1.48 \pm 1.8^{\mathrm{b}}$ & $1.48 \pm 0.4^{\mathrm{b}}$ & $1.47 \pm 0.5^{\mathrm{b}}$ & $1.48 \pm 0.8^{\mathrm{b}}$ & $1.47 \pm 0.3^{\mathrm{b}}$ \\
\hline 4 & $1.70 \pm 1.3^{\mathrm{a}}$ & $1.70 \pm 0.9^{\mathrm{a}}$ & $1.64 \pm 0.8^{b}$ & $1.66 \pm 1.2^{\mathrm{a}}$ & $1.69 \pm 0.4^{\mathrm{a}}$ & $1.64 \pm 0.5^{\mathrm{b}}$ & $1.63 \pm 0.2^{\mathrm{b}}$ & $1.63 \pm 0.9^{b}$ & $1.64 \pm 0.7^{b}$ \\
\hline 5 & $1.87 \pm 0.9^{\mathrm{a}}$ & $1.84 \pm 0.6^{\mathrm{a}}$ & $1.87 \pm 0.3^{\mathrm{a}}$ & $1.87 \pm 0.3^{\mathrm{a}}$ & $1.89 \pm 0.8^{\mathrm{a}}$ & $1.70 \pm 0.8^{\mathrm{b}}$ & $1.75 \pm 0.4^{\mathrm{b}}$ & $1.75 \pm 0.1^{\mathrm{b}}$ & $1.76 \pm 1.1^{\mathrm{b}}$ \\
\hline 6 & $2.22 \pm 1.3^{\mathrm{a}}$ & $2.14 \pm 1.6^{\mathrm{b}}$ & $2.16 \pm 0.2^{\mathrm{a}}$ & $2.19 \pm 0.8^{\mathrm{a}}$ & $2.20 \pm 0.1^{\mathrm{a}}$ & $2.07 \pm 0.1^{\mathrm{b}}$ & $2.09 \pm 0.5^{\mathrm{c}}$ & $2.09 \pm 0.9^{\mathrm{c}}$ & $2.07 \pm 0.8^{\mathrm{c}}$ \\
\hline
\end{tabular}

$\mathrm{A}^{*}$ : Dried chicken meat soup powder

$\mathrm{B}^{* *}$ : Dried mushroom soup powder

$\mathrm{C}^{* * * *}$ : Dried blend of chicken meat and mushroom soup powder

Mean \pm standard error $(n=3)$

Means within raw with different letters are significantly $(\mathrm{p}<0.05)$

Table 7. Thiobarbituric acid value of some blends dried soup during storage

\begin{tabular}{|c|c|c|c|c|c|c|c|c|c|}
\hline \multirow{2}{*}{ Months } & \multirow[b]{2}{*}{$\mathbf{A}^{*}$} & \multicolumn{4}{|c|}{$\mathbf{B}^{* *}$} & \multicolumn{4}{|c|}{$\mathbf{C}^{* * * * *}$} \\
\hline & & $\mathrm{B}(2.5 \%)$ & B(5\%) & $\mathrm{B}(7.5 \%)$ & B(10\%) & $\mathrm{C}(2.5 \%)$ & $\mathrm{C}(5 \%)$ & $\mathrm{C}(7.5 \%)$ & $\mathrm{C}(10 \%)$ \\
\hline 0 & $0.52 \pm 0.3^{\mathrm{a}}$ & $0.55 \pm 0.5^{\mathrm{a}}$ & $0.55 \pm 0.9^{\mathrm{a}}$ & $0.52 \pm 0.3^{\mathrm{a}}$ & $.55 \pm 0.9^{\mathrm{a}}$ & $0.52 \pm 0.6^{\mathrm{a}}$ & $0.52 \pm 0.0^{\mathrm{a}}$ & $0.52 \pm 0.6^{\mathrm{a}}$ & $0.55 \pm 0.3^{\mathrm{a}}$ \\
\hline 1 & & & & 0.7 & 0.7 & & $0.66 \pm 0.8^{\mathrm{b}}$ & $6 \pm 0.5^{\mathrm{b}}$ & \\
\hline 2 & $0.88 \pm 0$ & $0.81 \pm 0.5^{\mathrm{b}}$ & $0.82 \pm 0.5^{\mathrm{b}}$ & $0.83 \pm 0.2^{\mathrm{a}}$ & $0.85 \pm 0.9^{\mathrm{a}}$ & $0.78 \pm 0.3^{\mathrm{b}}$ & $0.77 \pm 0.2^{\mathrm{b}}$ & $0.77 \pm 0.4^{\mathrm{b}}$ & $0.78 \pm 0.1^{\mathrm{b}}$ \\
\hline 3 & $0.98 \pm 0$ & $0.89 \pm 0$ & 0.95 & $0.95 \pm 0.2^{\mathrm{a}}$ & $0.99 \pm 0.2^{\mathrm{a}}$ & $0.85 \pm 0.1^{\mathrm{c}}$ & $0.86 \pm 0.3^{\mathrm{c}}$ & $0.90 \pm 0.8^{\mathrm{b}}$ & $0.89 \pm 0.6^{\mathrm{b}}$ \\
\hline 4 & & $1.11 \pm 0.4^{\mathrm{b}}$ & $1.13 \pm 0.1^{\mathrm{b}}$ & $1.11 \pm 0.8^{\mathrm{b}}$ & $1.16 \pm 0.8^{\mathrm{a}}$ & $1.07 \pm 0.0^{\mathrm{c}}$ & $1.09 \pm 0.2^{\mathrm{c}}$ & $1.12 \pm 1.0^{\mathrm{b}}$ & $1.14 \pm 0.2^{\mathrm{ab}}$ \\
\hline 5 & $1.35 \pm 0.1^{\mathrm{a}}$ & $1.28 \pm 0.8^{\mathrm{b}}$ & $1.24 \pm 1.0^{c}$ & $1.20 \pm 0.7^{\mathrm{c}}$ & $1.33 \pm 0.3^{\mathrm{a}}$ & $1.30 \pm 0.1^{\mathrm{a}}$ & $1.33 \pm 0.1^{\mathrm{a}}$ & $1.28 \pm 0.2^{\mathrm{b}}$ & $1.29 \pm 0.9^{\mathrm{b}}$ \\
\hline 6 & $1.53 \pm 0.3^{\mathrm{a}}$ & $1.42 \pm 0.6^{\mathrm{b}}$ & $1.54 \pm 0.0^{\mathrm{a}}$ & $1.54 \pm 0.1^{\mathrm{a}}$ & $1.63 \pm 0.7^{\mathrm{a}}$ & $1.41 \pm 0.3^{\mathrm{b}}$ & $1.39 \pm 0.5^{\mathrm{b}}$ & $1.44 \pm 0.1^{\mathrm{b}}$ & $1.39 \pm 0.3^{\mathrm{b}}$ \\
\hline
\end{tabular}

$\mathrm{A}^{*}$ Dried chicken meat soup powder

$\mathrm{B}^{* *}$ : Dried mushroom soup powder

$\mathrm{C}^{* * * *}$ : Dried blend of chicken meat and mushroom soup powder

Mean \pm standard error $(n=3)$

Means within raw with different letters are significantly $(\mathrm{p}<0.05)$

Microbiological analyses:-

Total plate count (TPC)

It is well known that total plate count have been used to assess sanitary quality, organoleptic ability and safely of fresh and processed foods.Chen (1990) reported that the primary problem in food preser-vation is to prevent the growth of bacteria and other food spoilage microorganisms. Also, the prevention of microbiological deterioration is often considered to be the most important factor in meat and poultry preservation. At (1974) Brayan, reported that the presence of viable microorganisms in dried food is the net result of microbial contamination of raw materials.

Generally when the moisture content of dehydrated food is below $8 \%$ microorganisms do not grow while when moisture content is above $18 \%$ some microorganisms may be reproduced gradually (Luh \& woodroof, 1975).

Therefore, TPC present in processed blends dried chicken soup and during storage at room temperature up to 6 months was evaluated and the obtained results are shown in Table (8).

Tables 9(I, II) revealed that TPC of processed blends (A, B and C) markedly increased in all blends and at all mixing ratio. The highest total plate count was found in blend (B) at the end of the storage period for both prepared soup; in hot water. This could be attributed to the effect of heat on bacteria, which decreased the number of bacteria.The growth of bacteria, yeasts and a mould is also dependent on temperature (Gortner et al., 1948).

\section{Coliform group}

The results shown in Table (8) represent the total number of coliform group present in some processed blends of dried and commercial soups.

It could be easily noted that all processed blends dried chicken soup samples were free of any E.coli bacterial contamination either before or after preparation in hot water. The freedom from coliforms could be considered as an index of good sanitary prevailing conditions created during the different steps of preparation and processing.

The results indicate that some commercial soup samples are free of coliform bacterial contamination 
when prepared the samples in hot water.This again is usually due to the effect of heat on bacteria.

\section{Moulds and Yeasts}

Table (8) revealed that moulds and yeasts increased by extending the storage period. Moulds and yeasts were higher in processed (B) blend of dried soup after 6 months of storage at room temperature as compared to other blends.

From the same given results of Table $8(I, \Pi)$ it could be observed that the number of moulds and yeasts was lower in soup prepared in hot water, So the heating have positive effect on mould and yeast growth.

Extending the storage period at room temperature increased the microbial count including mould and yeast cells count in processed dried chicken soup.

Data in Table (8) show that mould and yeast cells of commercial soup samples decreased when prepared in hot water and some samples were completely free from mould and yeast growth.

\section{Organoleptic evaluation of processed and commercial soups:}

In all food sorts, organoleptic evaluation is considered one of the most important parameter that can be taken as a final guide to determine their quality from the consumers' point of view. Evaluation of sensory properties especially dry mixed food (soup) are, however, governed by personal preference that is influenced by many factors ranging from the caprices of fashion; social, cultural, and religious patterns; psychological factors; variations in climate and in the general physical status of individuals in terms of; availability; and nutritional education(Amerine et al.,1965).

The organoleptic evaluation of the prepared products; processed dried soup blends and three type of commercial soups which are more favorite from the Egyptian consumer-or-consumed local soup (prepared in hot water and were used in preparation of some dishes,such as stuffed grape leaves and Jewy's mallow"molohia") are indicate in Table (9 I.II.III).

All the attributes including taste, odour, color, texture and overall acceptability of all soup blendes were moderately good and very good, having average score 7-9. Data in Table (9, I) indicated that the commercial soup had higher panelists score with processed blend A. The revealed that (A) blend had higher acceptability rather than $(\mathrm{C})$ blend and mixing ratio at $2.5 \%$ is the highest acceptability with anther ratio, no significant differences between mixing ratio.

Flavour represents one of the most important quality attributes contributing to the widespread consumption of soup. In addition to volatile compounds, the typical flavour of soup consists of non volatile taste components. Regardless of some granules and particles present, the taste of soup is primarily due to the presence of several small molecular weight water soluble substances including 5-mucleotides, free amino acids and soluble sugars (Litchfield, 1967).Taste, also called the palatable taste or the perception of satisfaction is a good taste commonly provided by the soup and an overall food flavour induced or enhanced by monosodium glutamate (Yamaguchi, 1979).

When both commercial and processed soups in prepared stuffed grape leaves (Table 9 II), the statistical analysis of the obtained results (mean) that commercial soup samples had comparative high scores for color, taste, odour and overall acceptability than processed (A) blend soup, this may be due monosodium glutamate (MSG )salt in blends of commercial soup as a flavour materials which improve the sensory properties of soup.

\begin{tabular}{|c|c|c|c|}
\hline $\begin{array}{ll}\text { Months } & \text { Samples } \\
\end{array}$ & TPC $\times 10^{5}$ & $\mathrm{M \& Y} \times 10^{3} \mathrm{CFU} / \mathrm{g}$ & Coliform group \\
\hline 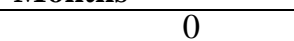 & NIL & NIL & NIL \\
\hline 1 & $12.66^{\mathrm{a}} \pm 2.0$ & NIL & NIL \\
\hline 2 & $14.33^{\mathrm{a}} 1.527$ & NIL & NIL \\
\hline 3 & $39.0^{\mathrm{b}} \pm 5.56$ & NIL & NIL \\
\hline 4 & $42.66^{\mathrm{b}} \pm 4.04$ & $0.20^{\mathrm{b}} \pm 0.173$ & NIL \\
\hline 5 & $72.66^{\mathrm{c}} \pm 5.50$ & $1.66^{\mathrm{c}} \pm 0.00$ & NIL \\
\hline 6 & $90.33^{\mathrm{d}} \pm 5.85$ & $2.100^{\mathrm{d}} \pm 0.173$ & NIL \\
\hline
\end{tabular}

${ }^{*}$ TPC: Total plate count

${ }^{* * *}$ M\&Y: Mould \& yeast ${ }^{* * *}$ CFU: Colony forming unit

$\mathrm{A}^{*}$ Dried chicken meat soup powder

$\mathrm{B}^{* *}$ : Dried mushroom soup powder

$\mathrm{C}^{* * * * *}$ : Dried blend of chicken meat and mushroom soup powder

Mean \pm standard error $(n=3)$

Means within raw with different letters are significantly $(\mathrm{p}<0.05)$ 
Litchfield (1967) indicated that 5, monosodium glutamate gave a meaty flavour and is a flavour enhancer, much stronger than (MSG). The synergistic effect of flavour 5-nucleotides with MSG- like components might greatly increase the taste of soups (Yamaguchi et al., 1971).

When comparing commercial and processed (A) and (C) blends soups, the (A) blend soup had higher acceptability rather than (C) blend soup and the best mixing ratio at $2.5 \%$, this may be due to (A) blend consists of only chicken meat as a source of protein.

Chicken meat was found to be a better source of flavour than bones, skin or a mixture of the three (Mountney \& Parkhurst, 1994). The results also revealed that the processed soup by using C (2.5\%) blend soup had higher panelists score comparing with anther ratio of mushroom additive. Maga (1981) showed that the higher score of the mushroom soup might be due to the alleged characteristic mushroom aromo, which is responsible for the widespread consumption of mushroom.

Apparent from the Table (9 III), it can be concluded from the panel test that Jewy's mallow prepared from commercial soup were more acceptable than those made with processed (A) blend soup. In addition, the same taste indicate that Jewy's mallow prepared by using processed (C) blend soup at level $2.5 \%$ mixing ratio were more acceptable than those of $5,7.5$ and $10 \%$, the same results indicated that no significant differences between processed (B) and (C) blends soup at level $2.5 \%$ mixing ratio in preparing Jewy's mallow, which had the best effect upon the sensory properties. Nishimura et al., (1988) reported that the pattern of free amino acids in soup was almost the same among beef and chicken. Therefore, it was suggested that the meaty taste of soups is determined by the pattern of the free amino acids, the high similarity of which makes the identification of animal species difficult. Also, Fuke\& Konosu (1991) reported that the brothy taste of beef, Pork and chicken soups could be reproduced by free amino acids, inosine 5-monophosphate and sodium chloride, indicating their important roles in producing the taste.

Their results assured and confirmed the suitability of such kind of soup to be one of the foodstuffs of higher acceptability.

\section{Table9. Organoleptic evaluation of commercial and processed dried soups}

Table9-I. Commercial and processed dried soups prepared in hot water

\begin{tabular}{|c|c|c|c|c|c|}
\hline Samples & Color & Taste & Odour & Texture & Over all \\
\hline $\begin{array}{c}\text { Commercial : } \\
\mathbf{1} \\
\mathbf{2} \\
\mathbf{3} \\
\mathbf{A}^{*}\end{array}$ & $\begin{array}{l}10 \pm 0.2^{\mathrm{a}} \\
10 \pm 0.2^{\mathrm{a}} \\
9.0 \pm 0.2^{\mathrm{a}} \\
8.0 \pm 0.1^{\mathrm{b}}\end{array}$ & $\begin{array}{l}10 \pm 0.3^{\mathrm{a}} \\
9.0 \pm 0.3^{\mathrm{a}} \\
8.5 \pm 0.1^{\mathrm{a}} \\
8.0 \pm 0.3^{\mathrm{b}}\end{array}$ & $\begin{array}{l}10 \pm 0.5^{\mathrm{a}} \\
8.5 \pm 0.6^{\mathrm{ab}} \\
8.0 \pm 0.8^{\mathrm{b}} \\
8.0 \pm 0.5^{\mathrm{b}}\end{array}$ & $\begin{array}{l}8.0 \pm 0.3^{\mathrm{b}} \\
9.0 \pm 0.3^{\mathrm{a}} \\
7.0 \pm 0.3^{\mathrm{c}} \\
7.0 \pm 0.1^{\mathrm{c}}\end{array}$ & $\begin{array}{l}9.0 \pm 0.0^{\mathrm{ab}} \\
9.5 \pm 0.2^{\mathrm{a}} \\
7.0 \pm 0.2^{\mathrm{b}} \\
6.5 \pm 0.1^{\mathrm{c}}\end{array}$ \\
\hline $\begin{array}{c}\text { Commercial } \\
\mathbf{1} \\
\mathbf{2} \\
\mathbf{3} \\
\mathbf{A}^{* *}\end{array}$ & $\begin{array}{l}10 \pm 0.1^{\mathrm{a}} \\
10 \pm 0.1^{\mathrm{a}} \\
8.0 \pm 0.3^{\mathrm{c}} \\
10 \pm 0.2^{\mathrm{a}}\end{array}$ & $\begin{array}{l}10 \pm 0.3^{\mathrm{a}} \\
8.0 \pm 0.6^{\mathrm{c}} \\
7.0 \pm 0.2^{\mathrm{c}} \\
10 \pm 0.3^{\mathrm{a}}\end{array}$ & $\begin{array}{c}10 \pm 0.1 \mathrm{a} \\
8.5 \pm 0.9^{\mathrm{ab}} \\
7.5 \pm 0.2^{\mathrm{c}} \\
10 \pm 0.2^{\mathrm{a}}\end{array}$ & $\begin{array}{l}8.0 \pm 0.5 \mathrm{a} \\
7.0 \pm 0.8^{\mathrm{b}} \\
7.0 \pm 1.1^{\mathrm{b}} \\
8.0 \pm 2.1^{\mathrm{a}}\end{array}$ & $\begin{array}{c}8.5 \pm 0.3^{\mathrm{ab}} \\
7 \pm 0.1^{\mathrm{c}} \\
6.5 \pm 5.2^{\mathrm{c}} \\
9.0 \pm 0.1^{\mathrm{a}}\end{array}$ \\
\hline $\begin{array}{c}\mathrm{C}^{*} \\
(\mathbf{5 \%}) \\
(\mathbf{5 \%}) \\
(\mathbf{7 . 5 \%}) \\
(\mathbf{1 0 \%})\end{array}$ & $\begin{array}{c}10 \pm 0.0^{\mathrm{a}} \\
9.5 \pm 0.6 \mathrm{ab} \\
9.0 \pm 0.3^{\mathrm{b}} \\
8.5 \pm 0.1^{\mathrm{bc}}\end{array}$ & $\begin{array}{l}10 \pm 0.1^{\mathrm{a}} \\
9.0 \pm 0.7^{\mathrm{ab}} \\
8.2 \pm 0.3^{\mathrm{bc}} \\
8.0 \pm 0.5^{\mathrm{c}}\end{array}$ & $\begin{array}{l}9 \pm 0.5^{\mathrm{ab}} \\
8.5 \pm 0.4^{\mathrm{ab}} \\
8.2 \pm 0.3^{\mathrm{b}} \\
8.1 \pm 1.1^{\mathrm{b}}\end{array}$ & $\begin{array}{l}8.0 \pm 0.2^{\mathrm{a}} \\
8.0 \pm 4.3^{\mathrm{a}} \\
7.9 \pm 0.1^{\mathrm{a}} \\
7.7 \pm 0.1^{\mathrm{ab}}\end{array}$ & $\begin{array}{c}9.0 \pm 0.5^{\mathrm{a}} \\
8.5 \pm 0.9^{\mathrm{ab}} \\
8.2 \pm 0.6^{\mathrm{b}} \\
8 \pm 0.1^{\mathrm{b}}\end{array}$ \\
\hline $\begin{array}{l}\mathrm{B} \\
(2.5 \%) \\
(5 \%) \\
(7.5 \%) \\
(10 \%)\end{array}$ & $\begin{array}{l}10 \pm 0.5^{\mathrm{a}} \\
9.5 \pm 0.6^{\mathrm{a}} \\
9.0 \pm 0.0^{\mathrm{ab}} \\
8.5 \pm 0.2^{\mathrm{b}}\end{array}$ & $\begin{array}{l}10 \pm 0.0^{\mathrm{a}} \\
9.0 \pm 1.3^{\mathrm{b}} \\
8.2 \pm 2.0^{\mathrm{bc}} \\
8.0 \pm 0.2^{\mathrm{c}}\end{array}$ & $\begin{array}{l}9.0 \pm 0.6^{\mathrm{a}} \\
8.5 \pm 0.6^{\mathrm{b}} \\
8.2 \pm 0.5^{\mathrm{b}} \\
8.1 \pm 0.8^{\mathrm{b}}\end{array}$ & $\begin{array}{l}8.0 \pm 0.6^{\mathrm{a}} \\
8.0 \pm 3.1^{\mathrm{a}} \\
7.98 \pm 3.1^{\mathrm{a}} \\
7.7 \pm 0.5^{\mathrm{ab}}\end{array}$ & $\begin{array}{c}9.0 \pm 0.3^{\mathrm{a}} \\
8.5 \pm 06^{\mathrm{ab}}{ }^{1} \\
8.2 \pm 0.6^{\mathrm{b}} \\
8.0 \pm 0.2^{\mathrm{bc}}\end{array}$ \\
\hline $\begin{array}{c}C^{*} \\
(2.5 \%) \\
(5 \%) \\
(7.5 \%) \\
(10 \%)\end{array}$ & $\begin{array}{l}8.4 \pm 1.1^{\mathrm{b}} \\
8.0 \pm 0.3^{\mathrm{b}} \\
7.0 \pm 1.2^{\mathrm{c}} \\
6.5 \pm 0.6^{\mathrm{d}}\end{array}$ & $\begin{array}{l}8.5 \pm 0.6^{\mathrm{bc}} \\
7.5 \pm 3.2^{\mathrm{c}} \\
6.5 \pm 0.1^{\mathrm{d}} \\
6.1 \pm 0.3^{\mathrm{e}}\end{array}$ & $\begin{array}{l}8.1 \pm 4.1^{\mathrm{b}} \\
7.5 \pm 0.2^{\mathrm{b}} \\
7.0 \pm 0.8^{\mathrm{c}} \\
7.0 \pm 1.0^{\mathrm{c}}\end{array}$ & $\begin{array}{l}8.0 \pm 1.2^{\mathrm{a}} \\
7.0 \pm 0.5^{\mathrm{b}} \\
6.8 \pm 0.8^{\mathrm{bc}} \\
6.5 \pm 0.7^{\mathrm{c}}\end{array}$ & $\begin{array}{c}8.1 \pm 0.6^{\mathrm{bc}} \\
7.5 \pm 3.0^{\mathrm{c}} \\
7 \pm 0.0^{\mathrm{c}} \\
6.5 \pm 4.1^{\mathrm{d}}\end{array}$ \\
\hline
\end{tabular}

A*: Dried chicken meat soup powder

B**: Dried mushroom soup powder

C***: Dried blend of chicken meat and mushroom soup powder

Mean \pm standard error $(n=3)$

Means within raw with different letters are significantly $(\mathrm{p}<0.05)$ 
Table 9-II. Commercial and processed dried soups prepared in Jewy's mallow

\begin{tabular}{|c|c|c|c|c|}
\hline Samples & Color & Taste & Odour & Over all \\
\hline 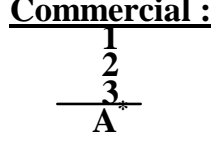 & $\begin{array}{c}10 \pm 0.1^{\mathrm{a}} \\
10 \pm 0.6^{\mathrm{a}} \\
9 \pm 0.3^{\mathrm{b}} \\
8.5 \pm 2.1^{\mathrm{b}}\end{array}$ & $\begin{array}{l}10 \pm 0.1^{\mathrm{a}} \\
10 \pm 0.3^{\mathrm{a}} \\
9 \pm 0.3^{\mathrm{b}} \\
8 \pm 0.5^{\mathrm{c}}\end{array}$ & $\begin{array}{l}10 \pm 0.5^{\mathrm{a}} \\
8 \pm 0.6^{\mathrm{b}} \\
7 \pm 0.3^{\mathrm{c}} \\
7 \pm 0.2^{\mathrm{c}}\end{array}$ & $\begin{array}{l}10 \pm 0.2^{\mathrm{a}} \\
9 \pm 0.0 \mathrm{a}^{\mathrm{b}} \\
7.5 \pm 1.1^{\mathrm{b}} \\
7.5 \pm 0.9^{\mathrm{b}}\end{array}$ \\
\hline 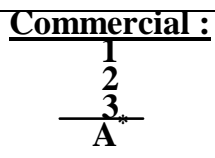 & $\begin{array}{l}10 \pm 0.6^{\mathrm{a}} \\
9 \pm 0.2^{\mathrm{b}} \\
8.5 \pm 1.1^{\mathrm{c}} \\
10 \pm 0.1^{\mathrm{a}}\end{array}$ & $\begin{array}{c}9 \pm 0.1^{\mathrm{b}} \\
9 \pm 0.9^{\mathrm{b}} \\
8 \pm 0.5^{\mathrm{c}} \\
10 \pm 0.3^{\mathrm{a}}\end{array}$ & $\begin{array}{c}9 \pm 0.3^{\mathrm{b}} \\
8 \pm 0.1^{\mathrm{c}} \\
7 \pm 0.5^{\mathrm{c}} \\
10 \pm 0.1^{\mathrm{a}}\end{array}$ & $\begin{array}{c}9.5 \pm 0.6^{\mathrm{a}} \\
9 \pm 0.1^{\mathrm{ab}} \\
8.5 \pm 0.2^{\mathrm{ab}} \\
10 \pm 0.1^{\mathrm{a}}\end{array}$ \\
\hline $\begin{array}{c}C^{*} \\
(2.5 \%) \\
(5 \%) \\
(7.5 \%) \\
(10 \%)\end{array}$ & $\begin{array}{l}10 \pm 0.1^{\mathrm{a}} \\
9.5 \pm 0.9^{\mathrm{b}} \\
9 \pm 0.8^{\mathrm{b}} \\
8.5 \pm 0.9^{\mathrm{c}}\end{array}$ & $\begin{array}{c}10 \pm 0.1^{\mathrm{a}} \\
9 \pm 0.1^{\mathrm{b}} \\
8.8 \pm 0.2^{\mathrm{bc}} \\
8.5 \pm 0.5^{\mathrm{bc}}\end{array}$ & $\begin{array}{l}10 \pm 0.1^{\mathrm{a}} \\
9 \pm 0.2^{\mathrm{b}} \\
8.5 \pm 0.1^{\mathrm{b}} \\
8 \pm 0.1^{\mathrm{c}}\end{array}$ & $\begin{array}{l}10 \pm 0.1^{\mathrm{a}} \\
9.5 \pm 0.5^{\mathrm{a}} \\
8.5 \pm 0.8^{\mathrm{b}} \\
8.3 \pm 0.9^{\mathrm{b}}\end{array}$ \\
\hline $\begin{array}{l}\mathbf{B} \\
(2.5 \%) \\
(5 \%) \\
(7.5 \%) \\
(10 \%)\end{array}$ & $\begin{array}{c}10 \pm 0.5^{\mathrm{a}} \\
9.5 \pm 0.4^{\mathrm{a}} \\
9 \pm 0.8^{\mathrm{a}} \\
8.5 \pm 0.3^{\mathrm{b}}\end{array}$ & $\begin{array}{c}10 \pm 0.8^{\mathrm{a}} \\
9 \pm 0.8^{\mathrm{ab}} \\
8.8 \pm 0.6^{\mathrm{ab}} \\
8.5 \pm 0.3^{\mathrm{b}}\end{array}$ & $\begin{array}{c}10 \pm 0.3^{\mathrm{a}} \\
9 \pm 0.1^{\mathrm{ab}} \\
8.5 \pm 0.2^{\mathrm{b}} \\
8 \pm 0.1^{\mathrm{b}}\end{array}$ & $\begin{array}{c}10 \pm 0.2^{\mathrm{a}} \\
9.5 \pm 0.2^{\mathrm{a}} \\
9 \pm 0.7^{\mathrm{a}} \\
8.5 \pm 0.5^{\mathrm{ab}}\end{array}$ \\
\hline $\begin{array}{l}\mathrm{C}^{*} \\
(2.5 \%) \\
(\mathbf{5 \%} \%) \\
(\mathbf{1 0 \%})\end{array}$ & $\begin{array}{c}9 \pm 0.2^{\mathrm{a}} \\
8.5 \pm 0.0^{\mathrm{b}} \\
8 \pm 0.2^{\mathrm{b}} \\
7.5 \pm 1.3^{\mathrm{b}}\end{array}$ & $\begin{array}{c}8.5 \pm 0.2^{\mathrm{b}} \\
8 \pm 0.6^{\mathrm{bc}} \\
7.5 \pm 0.6^{\mathrm{c}} \\
6 \pm 0.8^{\mathrm{g}}\end{array}$ & $\begin{array}{c}8 \pm 0.3^{\mathrm{b}} \\
7.5 \pm 0.4^{\mathrm{c}} \\
7 \pm 0.7^{\mathrm{c}} \\
7 \pm 0.7^{\mathrm{c}}\end{array}$ & $\begin{array}{l}8 \pm 0.9^{\mathrm{ab}} \\
7.5 \pm 0.6^{\mathrm{b}} \\
7.2 \pm 0.3^{\mathrm{b}} \\
6.5 \pm 05^{\mathrm{c}}\end{array}$ \\
\hline
\end{tabular}

$\mathrm{A}^{*}$ : Dried chicken meat soup powder

$\mathrm{B}^{* *}:$ Dried mushroom soup powder

$\mathrm{C}^{* * * *}$ : Dried blend of chicken meat and mushroom soup powder

Mean \pm standard error $(n=3)$

Means within raw with different letters are significantly $(\mathrm{p}<0.05)$

Table 9-III: Commercial and processed dried soups prepared in stuffed grape leaves

\begin{tabular}{|c|c|c|c|c|c|}
\hline Samples & Color & Taste & Odour & Texture & Over all \\
\hline 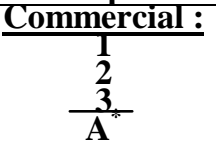 & $\begin{array}{l}10 \pm 0.2^{\mathrm{a}} \\
10 \pm 0.2^{\mathrm{a}} \\
9 \pm 0.2^{\mathrm{a}} \\
8 \pm 0.1^{\mathrm{b}}\end{array}$ & $\begin{array}{c}10 \pm 0.3 \mathrm{a} \\
9 \pm 0.3 \mathrm{a} \\
8.5 \pm 0.1 \mathrm{ab} \\
8 \pm 0.3 \mathrm{~b}\end{array}$ & $\begin{array}{c}10 \pm 0.5 \mathrm{a} \\
8.5 \pm 0.6 \mathrm{ab} \\
8 \pm 0.8 \mathrm{~b} \\
8 \pm 0.5 \mathrm{~b}\end{array}$ & $\begin{array}{l}9 \pm 0.9 \mathrm{a} \\
9 \pm 0.2 \mathrm{a} \\
8 \pm 1.0 \mathrm{~b} \\
7 \pm 0.9 \mathrm{~b}\end{array}$ & $\begin{array}{c}9.5 \pm 0.9^{\mathrm{a}} \\
9 \pm 0.3^{\mathrm{a}} \\
8 \pm 0.4^{\mathrm{b}} \\
7.5 \pm 0.4^{\mathrm{b}}\end{array}$ \\
\hline $\begin{array}{c}\text { Commercial: } \\
\begin{array}{l}\mathbf{2} \\
\frac{3}{3} \\
\mathbf{A}^{* *}\end{array}\end{array}$ & $\begin{array}{c}10 \pm 0.2^{\mathrm{a}} \\
9 \pm 0.3^{\mathrm{a}} \\
8 \pm 0.6^{\mathrm{b}} \\
10 \pm 0.4^{\mathrm{a}}\end{array}$ & $\begin{array}{c}9 \pm 0.6^{\mathrm{a}} \\
8.5 \pm 0.1^{\mathrm{b}} \\
8 \pm 0.1^{\mathrm{b}} \\
10 \pm 0.3^{\mathrm{a}}\end{array}$ & $\begin{array}{c}8.5 \pm 0.6^{\mathrm{ab}} \\
8 \pm 0.1^{\mathrm{b}} \\
8 \pm 0.3^{\mathrm{b}} \\
10 \pm 0.5^{\mathrm{a}}\end{array}$ & $\begin{array}{l}9 \pm 0.4^{\mathrm{a}} \\
8 \pm 0.3^{\mathrm{b}} \\
7 \pm 0.2^{\mathrm{c}} \\
9 \pm 0.2^{\mathrm{a}}\end{array}$ & $\begin{array}{c}9 \pm 0.2^{\mathrm{a}} \\
8 \pm 0.2^{\mathrm{c}} \\
7.5 \pm 0.2^{\mathrm{c}} \\
9.5 \pm 0.1^{\mathrm{a}}\end{array}$ \\
\hline $\begin{array}{c}\mathbf{B}^{*} \\
(2.5 \%) \\
(\mathbf{5 \%} \%) \\
(\mathbf{7 . 5 \%})\end{array}$ & $\begin{array}{l}10 \pm 0.8^{\mathrm{a}} \\
9 \pm 0.1^{\mathrm{a}} \\
8.5 \pm 0.3^{\mathrm{b}} \\
8.5 \pm 0.6^{\mathrm{b}}\end{array}$ & $\begin{array}{c}10 \pm 0.3^{\mathrm{a}} \\
9 \pm 0.4^{\mathrm{a}} \\
8 \pm 0.3^{\mathrm{b}} \\
7.5 \pm 0.6^{\mathrm{c}}\end{array}$ & $\begin{array}{c}10 \pm 0.8^{\mathrm{a}} \\
9 \pm 0.1^{\mathrm{ab}} \\
8.5 \pm 0.1^{\mathrm{ab}} \\
8 \pm 0.1^{\mathrm{b}}\end{array}$ & $\begin{array}{l}9 \pm 06^{\mathrm{a}} \\
9 \pm 0.1^{\mathrm{a}} \\
8 \pm 0.3^{\mathrm{b}} \\
8 \pm 0.8^{\mathrm{b}}\end{array}$ & $\begin{array}{c}9.5 \pm 0.2^{\mathrm{a}} \\
9 \pm 0.1^{\mathrm{a}} \\
8.5 \pm 0.2^{\mathrm{b}} \\
8.2 \pm 0.5^{\mathrm{bc}}\end{array}$ \\
\hline $\begin{array}{c}\mathbf{B} \\
(2.5 \%) \\
(5 \%) \\
(7.5 \%) \\
(\mathbf{1 0 \%})\end{array}$ & $\begin{array}{l}10 \pm 0.1^{\mathrm{a}} \\
9 \pm 0.4^{\mathrm{a}} \\
8.5 \pm 0.1^{\mathrm{b}} \\
8.5 \pm 0.2^{\mathrm{b}}\end{array}$ & $\begin{array}{c}10 \pm 0.3 \\
9 \pm 0.1^{\mathrm{a}} \\
8 \pm 0.3^{\mathrm{b}} \\
7.5 \pm 0.2^{\mathrm{b}}\end{array}$ & $\begin{array}{c}10 \pm 0.3^{\mathrm{a}} \\
9 \pm 0.4^{\mathrm{a}} \\
8.5 \pm 0.1^{\mathrm{ab}} \\
8 \pm 0.3^{\mathrm{b}}\end{array}$ & $\begin{array}{l}9 \pm 0.5^{\mathrm{a}} \\
9 \pm 0.8^{\mathrm{a}} \\
8 \pm 0.2^{\mathrm{b}} \\
8 \pm 0.9^{\mathrm{b}}\end{array}$ & $\begin{array}{c}9.5 \pm 0.1^{\mathrm{a}} \\
9 \pm 0.1^{\mathrm{a}} \\
8.5 \pm 0.2^{\mathrm{a}} \\
8.2 \pm 0.1^{\mathrm{ab}}\end{array}$ \\
\hline $\begin{array}{c}\mathbf{C}^{*} \\
(2.5 \%) \\
(5 \%) \\
(7.5 \%) \\
(10 \%)\end{array}$ & $\begin{array}{l}9 \pm 0.3^{\mathrm{a}} \\
8.5 \pm 0.2^{\mathrm{b}} \\
7.5 \pm 0.6^{\mathrm{c}} \\
7 \pm 0.1^{\mathrm{c}}\end{array}$ & $\begin{array}{c}8 \pm 0.1^{\mathrm{b}} \\
7.5 \pm 0.2^{\mathrm{b}} \\
7 \pm 0.1^{\mathrm{c}} \\
6 \pm 0.4^{\mathrm{c}}\end{array}$ & $\begin{array}{c}8 \pm 0.2^{\mathrm{b}} \\
7.5 \pm 0.3^{\mathrm{bc}} \\
7 \pm 0.4^{\mathrm{c}} \\
6.5 \pm 0.5^{\mathrm{c}}\end{array}$ & $\begin{array}{c}8 \pm 0.2^{\mathrm{b}} \\
\frac{7.5 \pm 0.2^{\mathrm{bc}}}{6.5 \pm 0.1^{\mathrm{c}}} \\
6 \pm 0.3^{\mathrm{c}}\end{array}$ & $\begin{array}{c}8 \pm 0.6^{\mathrm{ab}} \\
7.5 \pm 0.3^{\mathrm{b}} \\
7 \pm 0.5^{\mathrm{b}} \\
6 \pm 0.7^{\mathrm{c}}\end{array}$ \\
\hline
\end{tabular}

\footnotetext{
$\mathrm{A}^{*}$ : Dried chicken meat soup powder

$\mathrm{B}^{* *}$ : Dried mushroom soup powder

$\mathrm{C}^{* * * *}$ : Dried blend of chicken meat and mushroom soup powder

Mean \pm standard error $(n=3)$

Means within raw with different letters are significantly $(\mathrm{p}<0.05)$
} 


\section{REFERENCES}

Anonymous.1986. Manual of food quality control.7. Analysis: General Techniques. Additives. Contamination and Compositions. FAO (Ed.) pp. 203-228 Collocation FAO, Rome.

AOAC. 2000. Official Methods of Analysis' $17^{\text {th }}$ ed. Association of Official Analytical Chemists Published by the Association of Official Analysis Chemists, Inc, USA.

Axtell, B.1992. Some economic considerations of drying. J food chain. 7:17-18.

Bolton, R.P.;Heaton,K.W. and Burroughs, L.F.1981. The role of dietary fiver in satiety. Glucose and insulin: Studies with fruit and fruit juice. American Journal of Clinical Nutrition 34:211-217.

Bridson, E.Y.1990. The Oxoid Manual. $6^{\text {th }}$ Ed. Unipath Ltd, Wade Roade, Basingstoke RG24 OPN.

Bryan, F.L.1974. Microbiological food hazards to dry based on epidemiological information J. Food Tech., 28(9)5266.

Bulgarian. Standard. 1975. Dried soup, Bulgarian Standard; BDS 12634-75.

Chen, C.S. 1990. Predicting water activity in solutions of mixed solutes. J.Food Sci., 55(2):494-497, 515.

Chiang, P.D.; Yen, C.T. \& Mau, J.L. 2007. Non volatile taste components of various broth cubes. Food Chem., 101:932-937.

Crisan, E.V. \& Sands, A.1978. Edible mushrooms: nutritional value. In: S.T. chang and W.A.Hayes (Eds). The biology and cultivation of edible mushrooms.PP.137-165.New York: Academic Press.

Cuesta, C.;Sanchez-muniz, F.J.; Garido-Polonio, C.; LopezVarela, S. \& Arroya ,R.1993. Thermoxidative and hydrolytic changes in sunflower oil used in dryings with a fast turnover of fresh oil. J.Am. Oil Chem. Soc., 70(11):1069-1073.

Dimeglio, D.P.\&Mattes, R.D.2000. Liquid versus solid carbohydrate :Effects on food intake and body weight. International Journal of Obesity 24:794-800.

Duranti,M \&Cerletti ,P.1979.Amino acid composition of seed protein,J.Agric.Food Technol.,43;102=116

Egan,H.;Kirk, R.S.\&Sawyer,R.1987. In Pearson's Chemical Analysis of foods, Eighth edition. Langman Scientific and Technical. Essex, England.

Egorova, Z.E. 1982. Changes in micro flora in dried soup during storage. Izvestiya Vysshikh Uchebnykn Zavedenii, Pishchevaya Tekhologiya; 6, 51-55.C.F. FSTA-11-G 830.

FAO/WHO/UNU 1985.Energy and protein requirements: report of a joint FAO/WHO/UNU. Expert Consolation. World Health Organization Technical Report Series 724, WHO, Geneva.935-1015.

Fey, M.S. \& Regenstein, J.M.1982. Extending shelf life of fresh wet Red hake and Salmon using $\mathrm{CO}_{2}-\mathrm{O}_{2}$ modified atmosphere and potassium sorbet ice at $1{ }^{\circ} \mathrm{C}$. J. Food Sci., 47:1048-1054.

Flood, J.E. and Rolls, B.J.2007. Soup preloads in a variety of forms reduce meal energy intake. Appetite 10:1-9.

Flynn,A. \& Fox, P.F. 1981. Proximate and mineral composition of Irish dried soups. Irish J.of Food Sci. and Tech., 5 (1)59-64.

Folch, J.;Lees, M. \& Sloane Stanley, G.H.1957. A simple method for the isolation and Purification of total lipids from animal tissues. J.Biol. Chem., 226:497-509.

Frazier, W.C. 1978 preservation by drying in food microbiology $2^{\text {nd }}$ ed:W.C.Frazier, p.p 122-130. Tata MCG raw-hill publishing company L.T.D Bombay-New Delhi.

Fuke, S. \& Konosu, S.1991. Taste active components in some foods. Physiology and Behavior 49(5):863-868.

Goldman, E. \& Chodlia, L. 1966. The use of smoke concentrates in sausage production. Meat Industry USSR, $4: 32-36$.

Gortner, W.A.; Erdman, F.S. \& Master Man, N.K.1948. Principles of food freezing. New York. John Wiley and Sons, INC., London. Chapman \& Hall, Limited.

Gray, J.I.1978. Measurement of lipid oxidation. A. review J.A.O.C.S., 55.539-546.

Himaya, A. \& Louis- Sylvestre, J.1998. The effect of soup on saliation. Appetite, 30:199-210.

Hobbs, B.C.\& Gilbert, R.J. 1978. Food poisoning and food hygiene. $4^{\text {th }}$ ed. The English language book society and Edward Arnold (publishers) Itd, London.

Hoffman, C.J.\& Zabik, M.E.1985. Effects of microwave cooking/ reheating on nutrients and food systems. A review of recent studies. J.Am. Diet. Assoc., 85:922.

Jacobson, G.A.1961. Some aspects of chemical assessment of fat and oil flavors. Proc. Flavor Chemistry Symposium, pp. 165-178, Campbell Soup Co., Camden, U.S.A.

Kalac, P.\& Svoboda, L.2000. A review of trace element concentration in edible mushroom. Food Chem., 69(3):273-281.

Karel, M.1973. Symposium: protein interactions in biosystems. Protein-Lipid interactions. J.Food Sci., 38:756.

Karel, M.1973. Symposium: protein interactions in biosystems. Protein-Lipid interactions. J. Food Sci., 38:756.

Kissileff, H.R.; Gruss,L.P.; Thornton, J. and Jordan, H.A.1984. The satiating efficiency of foods. Physiology \& Behavior 32:319-332.

Klein, B.P.;Kuo, C.H.Y. and Boyd, G.1981.Folacin and ascorbic acid retention in fresh raw microwave and conventionally cooked spinach. J.Food Sci., 46:640.

Kohno,K.;Hayakawa, F.;Xichang, W.\&Shunsheng,C.2005. Comparative study on flavor preference between Tapanese and Chinese for dried Bonito stock and chicken Bouillon. J. Food Sci., 70(3):S193-S198. 
Krejcova, A.;Cernohorsky, T. \& Meixner,D. 2007. Elemental analysis of instant soups and seasoning mixtures by ICPOES. Food Chem.

Kuniori, T.;Nishiyama,J.\& Matsumoto,H.1979. Effect of mushroom extract on the physical properties of dough. Cereal Chem., 53:420-428.

Kuroda, M. \& Harada, T.2004. Fractionation and characterization of the macromolecular meaty flavor enhancer from beef meat extract. J.Food Sci., 69(7):C542C548.

Laboure, H.; Van Wymelbeke, V; Fantino ,M.\& Nicolated S.2002.Behavioral, Plasma and Calorimetric changes related to food texture modification in men. American Journal of Physiology-Regulatory Integrative and Comparative Physiology, 282(5):R1501-R1511.

Li,x.; Staszewski, L.; Xu, H.;Durick,K.;Zoller, M.\& Adler, E.2002. Human receptors for sweet and umami taste. In: proceedings of the National Academy of Sciences of the United States of America. Vol. 99, pp. 4692-4696.

Litchfield, J.H.1967. Morel mushroom mycelium as a food flavouring material. Biotechno. And Bioeng., 9:289-304.

Luh, B.S.\&Woodroof, J.G.1975. Commercial vegetable processing. The Avi publishing company, inc., Westport. Connecticut, U.S.A.

Maga, J.A.1981. Mushroom flavour. J.Agric. Food Chem., 29:1-4.

Matsuishi, M.;Igeta, M.;Takeda, S.\& Okitani, A.2004. Sensory factors contributing to the identification of the animal species of meat. J.Food Sci., 69(6):S218-S220.

Mau, J.L.2005. The umami taste of edible and medicinal mushrooms. International Journal of Medicinal mushrooms 7:113-119.

Meligaard,M.,Civille,G.V.\&Carr,T.1999.Sensory Evaluation Techniques. $3^{\text {rd }}$ ed,CRC Press, New york.

Moore, S.;Spachman, D.H. \& Stein, W.1958. Chromatography of amino acid on salphonated polytrene resins. Anal. Chem., 30:1185-1189.

Mountney, G.J. \& Parkhurst, C.R.1994. Poultry products technology. $3^{\text {th }}$ pp.73. An Imprint of The Haworth press, Inc., New York, London.

Nishimura, T.;Rhue, M.R.; Okitani, A .\&Kato, H. 1988. Components contributing to the improvement of meat taste during storage. Agric. Biol. Chem., 52:2323-2330.

Norton, g.n.m.;Anderson, A.S.\&Hetherington, M.M.2006. Volume and variety: Relative effects on food intake. Physiology \& Behavior, 87:714-722.

Nottingham, P.M.1971. Microbiological quality control in meat industry. J.Sci. Food Agric., 11:436.

Osman, M.A.,El damaty, S .Shaheen,A.\& Ibrahim M.M.(1991). Producting of precooked dehydrated soups III .preparation of beaf meat and chicken soup and chemical, sensory and keeping quality evaluations. Egypt,J.Food Sci 19(3):257-267.

Pavloveski, P.E. \& Palmin, V.V.1963. Biochemistry of meat and meat products. Food Industry Pub. Moscow.
Pearson, A.M.;Love, J.D \&Shorland, F.B.1977. Warmed over flavor in meat, poultry and fish. Adv. Food Res., 23:2-61.

Pelczar, M.J.; Reid, R.D. \& Chen, E.C. 1982. "Microbiology". $4^{\text {th }}$ Ed., McGraw- Hill publishing Inc., N.Y., U.S.A.

Radwan,S.S.1978.Coupling of two dimension thin layer chromatografhy with gas chromatography for the quantitative analysis of lipids classes and their constituent fatty acids.J.Chromatography Science, 16:538-542.

Ranken M.D.,KiUR.C.\&Baker C.1997.Food Industries Manual 23 rd edition pp.477-478.Chapman and Hall, Great Britain

Rolls, B.J.; Castellanos, V.H.; Shide, D.J.;Miller, D.L.; Pelkman, C.L. and Thorwart, M.L.1997. Sensory properties of a non absorbable fat substitute did not affect regulation of energy intake. American Journal of Clinical Nutr., 65:1375-1383.

Rolls, B.J.; Fedoroff, I.C.; Guthrie, J.F. and Laster, L.J.1990a. Foods with different satiating effects in humans. Appetite 15:115-126.

Rolls, B.J.;Bell, E.A. and Thorwart, M.L1999. Water incorporated into a food but not served with a food decreases energy intake in lean women. American Journal of Clinical Nutr., 70:448-455.

Rolls, B.J.;Fedoroff, I.C.;Guthrie, J.F.and Laster, L.J. 1990 b. Effects of temperature and mode of presentation on hunger, thirst and food intake in humans. Appetite 15:199208

Sales, J.1996. Histological, Biophysical and Chemical characteristics of different ostrich muscles. J.Sci. Food Agric., 70:109-114.

Sanders,T.\& Emery, B.2003. Molecular basis of human nutrition, Tylor \& Frances Inc., New York, USA .PP.37.

Santangelo, A.; Peracchi, M.; Conte, D.; Fraquelli, M. \& Porrini, M.1998. Physical state of meal effects gastric emptying, cholecystokinin release and satiety. British Journal of Nutrition 80:521-527.

SPSS 1999.Statistical package for Social Sciences.SPSS Inc.444 North Michigen Avenue,Chicago,IL 606 11,USA.

Varnam, A.H. \&Sutherland, J.P.1995. Meat and meat products. Technology, Chemistry and microbiology. Pp.405. Chapman \& Hall, London, Glasgow, Weinheim, New York, Tokyo, Melbourne, Madras.

Wikipedia.2007.Chickensoup.http://en.wikipedia.org/wiki/Chi ckensoup

Yamaguchi, S.; Yoshikawa, T.; Ikeda, S. \& Ninomiya, T.1971. Measurement of the relative taste intensity of some $\alpha$ - amino acid and 5- nucleotides. J.Food Sci., 36:846-849

Yamaguchi, S.1979. The umami taste. In J.C.Boudreau (Ed.), Food taste chemistry. ACS symposium series (115, pp. 3351). Washington, DC: American Chemical Society.

Younathan, M.T.;Marjan, Z.M. \&Arshad, F.B.1980.Oxidative rancioity in stored ground turkey and beef. J. Food Sci., 46:274-279. 


\section{الملخص العربي \\ مقارنة بين بَعْض مُنتَجاتِ الشوربةِ المُجَفَّفةِ المصنّعةِِ}

سميحة مُمَّمَ السيد

وقد أوضحت نتائج الدراسة أن عينات الشوربة التجارية أحتوت

على نسـب أعلى مـن معـدن الصـوديوم والخـواص الحسـية مقارنسة

بالعينات التى تم تصنيعها. وأظهرت نتائج التحليل أن رقم البيروكسيد-

حمض الثيوباربتيوريك(جم مالونالدهيد/كجم) والعد الكلى للبكتريا-

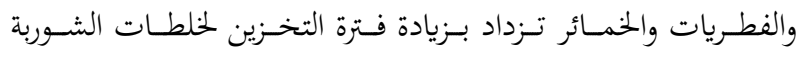

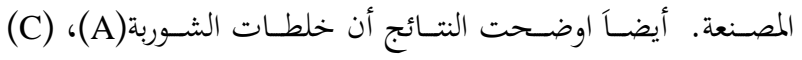

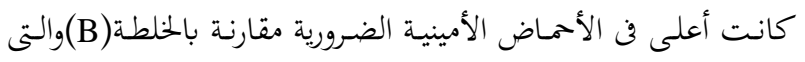

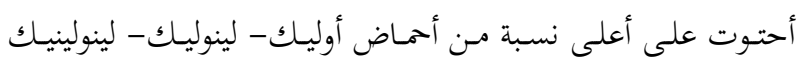

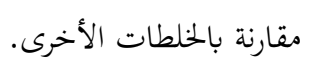

$$
\begin{aligned}
& \text { الشـوربة مـن الأغذيـة شـائعة الأستهلاك لجميـع المسـتويات في } \\
& \text { الوجبات نظرا لاها تعطى الأطعمة النكهة المميزة المقبولة. } \\
& \text { ومسن خـلال هـذه الدراسـة تم تصنيع ثلاثة خلطات مـن الشوربة }
\end{aligned}
$$

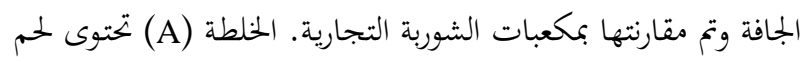

$$
\begin{aligned}
& \text { الدجاج فقط خلطة (C) تحتوى على عيش الغراب فقط ، الخلطة } \\
& \text { (B) } \\
& \text { وقــ أظهـرت النتـائج المتحصـل عليهـا أن هنـاك فروق معنويـة في }
\end{aligned}
$$

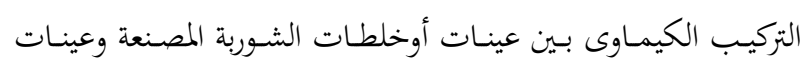

$$
\begin{aligned}
& \text { الشوربة التجارية المنتشرة في السوق المحلى. }
\end{aligned}
$$

